\title{
The Usage of Excommunication (Takfir) in the Ideology of Justice and Development Party (the AKP), Political Islamists of Turkey
}

\author{
Recep Dogan \\ Wisdom College, Brisbane, Australia \\ 97 Formby Street, Calamvale, QLD, Australia
}

Tel: 61-403-000-982 E-mail: drdogan66@ gmail.com

\author{
Received: June 18, 2018 Accepted: July 12, 2018 Published: June 13, 2018 \\ doi:10.5296/iss.v6i2.13290 URL: http://dx.doi.org/10.5296/iss.v6i2.13290
}

\begin{abstract}
The usage of excommunication goes back to the early history of Islam for the extreme Kharijite sect declared for the first time all other Muslims who did not agree with them as apostates and killed them brutally in the 7th century. The extreme mentality of the Kharijites has been witnessed in various extreme sects throughout Islamic history. More recently, Justice and Development Party (the AKP), the political Islamists of Turkey, has been using the concept of takfir (excommunication) against its opponents. In this essay, we will examine the concepts of faith (īmān) and disbelief (kufr) and then attempt to analyze the ruling AKP's usage of excommunication (takfir) on the basis of primary Islamic sources. The essay will seek the relation between the takfir and extremism as well as its connection with violence and terrorism by examining the ideology of the ruling AKP in Turkey.
\end{abstract}

Keywords: excommunication, takfir, apostate, Justice and Development Party, the AKP, Recep Tayyip Erdogan, the Turkish Directorate of Religious Affairs, the Diyanet, Fethullah Gulen, Hizmet Movement 


\section{Iman (Faith) and Kufr (Disbelief)}

Islam has three main components which are belief, practice and morality. The articles of Islamic faith are called "uș ūl" - the roots or essential parts (Jurjānī, 2014, p. 237). Uș ūl is the plural form of the Arabic word "aș l" which means a root, an essential part, or a main principle (Ibn Manzūr, 1999). Muslim scholars used the word "us ūl" in the meaning of essential part of Islam which is Islamic belief or main principles and articles of Islamic faith (Baqillānī, 1957, p.42). The practice of Islam, on the other hand, refers to practical parts of Islamic faith which all Muslims are required to do when they have necessary qualifications to be responsible such as coming of age and having mental health. This part is called in Islam as "furū" (branches), the plural of "far" which means a branch (Al Isfahānī, 1997). Faith is a foundation, root and essential while practice is a branch and obedience. Iman (faith) is acceptance of Islamic belief brought by Prophet Muhammed. (Jurjānī, 2014, p. 60).

The Arabic word "kufr" refers to disbelief and "takfir" refers to excommunication of a person or a group by labeling them with disbelief (Ibn Manzūr, 1999, 5/3897). In other words, takfir is the act of declaring someone or a group as disbeliever(s) (Zabīdīi, 1990, 14/50). If a person rejects or denies the articles of Islamic faith all together or just one of them he or she becomes "kāfir" (Rāzī, 1999, 2/42). If a Muslim does not, however, carry out his or her religious obligations this does not make him or her kāfir (unbeliever) rather he or she becomes a sinner (Yazir, 1997, 1/173). For this reason, it is extremely dangerous to call anyone as "kāfir" due to his or her negligence of religious duties. The Prophet strongly prohibited calling any Muslim as kāfir (Bukhari, 1997, Adab, 44) because such an approach opens the door for committing all kinds of evils against the person who is labelled as kāfir.

In the Qur'an, "īmān" (faith) and "“amal” (practice) are used together to emphasize the notion that a person can only be a perfect believer by having both parts in his or her daily life (Gölcük \& Toprak, 2001, p. 12). Nevertheless, the Qur'an does not label Muslims who do not practice Islamic rulings as "unbelievers"; rather, it calls them as sinners (Taftazān̄̄, 1991, p.276). This indicates that a person remains as a Muslim as long as he or she does not deny or reject any article of Islamic faith even if he or she does not practice Islamic rulings (Māturīî̄, 2006, p. 511). Once the Prophet warned Muslims with a strong emphasis by saying that whoever attributes kufr (unbelief) to a Muslim, he is like his murderer (Tirmidhī, 1967, 2/213). Ibn Umar stated that whoever calls a Muslim as a kāfir, he is nearer to disbelief (kufr) than the person whom he labeled as kāfir. Another time the Prophet stated that no one accuses another Muslim of being a kāfir, but it reflects back to him if the other is not a disbeliever as he called him (Bukhari, 1997, Adab, 44).

The usage of takfir in Islamic history goes back to the time of the extreme Kharijite sect which emerged in the time of Ali ibn Abi Tãlib, the fourth caliph of Islam (656-61). The Kharijites accused Caliph Ali and other Muslims with disbelief and then killed them brutally (Shahristān̄i, 1993, 1/132) because, according to their extreme mentality, kufr is a crime for which bloodshed is its due punishment (Baghdadi, n.d. p. 74). It can be argued that the usage of takfir is strongly related to the extreme mentality of all terrorist groups in Islamic history as it was the case for the Kharijites. 


\subsection{The Usage of Takfir by Political Islamists}

The Diyanet, the Directorate of Religious Affair in Turkey, which is supposed to speak according to Islamic principles, has become the political tool of the ruling AKP and its leader Erdogan. One of the basic principles of Islam is that it is not permissible to declare a Muslim group as a deviated sect (Māturīīī, 2006, p. 516). Moreover, it is strongly prohibited to declare any Muslim as infidel or apostate. However, Mehmet Görmez, the former head of the Diyanet from 2010 to 2017, declared the Hizmet Movement as "a deviated sect" and millions of its followers as "apostates" (The Diyanet, 2016). With his fatwa (religious verdict), he justified all injustices and persecutions done by the ruling AKP government against all of the Gülen sympathizers.

There is a strong similarity between the terrorist groups, such as ISIS and Al Qaeda, and the Diyanet with regards to labeling other Muslims as "apostates" and then legitimizing all kinds of injustices against them. Under the rule of AKP, Turkey's Directorate for Religious Affairs (Diyanet) has become more radical and extreme. By interpreting the Islamic sources according to the demands of the ruling AKP, the Diyanet only contributes to the radicalization process of Turkish people and worsens the existing problems. Currently, there is too much polarization, hatred, enmity and divisions among people in Turkey, and there seems no solution for them in a near future. At this stage, the Diyanet takes active part to spread enmity among the different segments of Turkish society by misinterpreting the religious sources and supporting violence with their extreme fatwas (Kenes, 2018). When this is done by the head of the Directorate of Religious Affairs (Diyanet), it gets worse and becomes more complicated for it leads the ignorant masses to violence against the sympathizers of the Hizmet Movement. Unfortunately, although people from the movement have never resorted to any violence or terrorist act, even when they are persecuted so deeply, Erdogan and the AKP declared the movement, including Gülen and all of his sympathizers, a "terrorist" group. In order to support his extreme opinion, the Diyanet issued a fatwa labeling the Hizmet Movement as a deviated sect (The Diyanet, 2016).

According to basic Islamic teachings, anyone who declares the testimony "There is no deity other than God and Muhammad is His Messenger" is accepted as a Muslim (Muslim, 1996, Iman, 1), and no one can call him or her as an "unbeliever or apostate." A Muslim is a person who believes in God, His angels, books, messengers, the afterlife and the Divine destiny (Bukhari, 1997, Iman, 1). Therefore, no institution has the authority to declare a Muslim who believes in these essentials of Islamic faith as an "unbeliever or apostate" (Ibn Ābidīn, 1987, 4/224).

An examination of the primary Islamic sources clearly shows that Muslims are forbidden to declare the excommunication of others since such an act would turn against themselves. Prophet Muhammad said, "Any person who calls his brother as 'O unbeliever' (has in fact done an act by which this unbelief) would return to him. If it were so (if the person is an unbeliever) as he asserted (then the unbelief of man was confirmed but if it was not true), then it turns back to him (to the man who labeled other Muslims as 'unbelievers')" (Muslim, 1996, Iman, 26). Although the Noble Prophet warned Muslims stating, "Insulting a Muslim is 
an evil act and fighting him or her is disbelief' (Muslim, 1996, Iman, 28), radical groups have ignored this type of clear religious texts and kept using others by disconnecting them from their actual context in an attempt to support their extreme ideology and aims.

In order to cover up the massive corruption allegations about his family members and some of the ministers in his cabinet, Erdogan labelled the general persecutors and other law enforcement officials as "betrayers" to their country (Solaker, 2014). Without having any strong evidence, he alleged that all those people were from the Hizmet Movement trying to undermine the AKP government (Solaker, 2014). At this stage, the Diyanet played a pivotal role by supporting Erdogan and the corrupted politicians with its religious fatwas (Kenes, 2018). Indeed, the Qur'an prohibits Muslims to label other Muslims as unbelievers to usurp their wealth:

O you who believe! When you go forth (to war) in God's cause, investigate with care until the situation becomes fully clear to you, and do not say to anyone who offers you (the greeting of) peace (thereby indicating his being a Muslim), "You are not a believer," seeking the fleeting gains of the present, worldly life; for with God are gains abundant. Even thus (as he now is) were you before (ignorant of faith and what being a Muslim is, and you too entered Islam with a similar word); but God has since then been gracious to you. So, investigate with care until the situation becomes fully clear to you. Surely God is fully aware of all that you do. (4:94)

The Noble Prophet clearly stated on many occasions that a person who performs the daily prayers and faces the Ka'ba is Muslim (Bukhari, 1997, Salah, 28). He often warned Muslims with regards to excommunicating each other, "Do not call people who face your Qibla (the Ka'ba) as 'unbeliever'” (Dāraqutn̄̄, 1996, 2/57).

Although Gülen and his sympathizers have dedicated their lives to the service of Islam and the common good of all humanity, they are accused with disbelief by the Diyanet due to the political pressure of the AKP (Yilmaz \& Bashirov, 2018). In reality, as it can clearly be seen over several decades, Gülen and his sympathizers are practicing Muslims who advocate moderate Islam (Hendrick, 2013). They have been serving in more than 170 countries for the betterment of society in every way and representing Islam as beautiful as they can. None of them are ever seen committing violence or resorting to terror in the name of "promoting" Islam. They don't have any extreme idea; rather, they represent a moderate Islam in their personal lives, embracing all humanity with compassion and mercy.

Gülen has produced more than 70 books in his native Turkish and most of them are translated into many world languages, including English (Esposito \&Yilmaz, 2010). Many academics have been working on his books and ideas and the Hizmet Movement in general. Some universities in various places in the world have opened chairs dedicated to his name (Çetin, 2010). If Gülen and the Hizmet Movement had any extreme tendency or inclination towards violence or terror, this would have been known easily for Gülen and the movement he inspired are well-known by countless academics and many other people all around the world.

\subsection{Comparing the Hizmet Movement with the Assassins under the Political Pressure}


Although Gülen and the movement he inspired are clearly away from any form of extremism, Turkey's Directorate of Religious Affairs (Diyanet) accused the followers of this movement with heresy. The head of Diyanet tried to establish a connection between Hassan Sabbah and Gülen on the basis of political motives (Diyanet, 2016). Hassan Sabbah was the founder of the Assassins (Nowell, 1947). This group was one of the medieval Ismaili-Shia sects and considered heretical movement in Islam (Shahristānī, 1993). Characterized also as a secret order of a mysterious man (old man of the mountain), it refers to the violence and terrorism of a Persian sect who often drugged themselves by means of hashish, and therefore called as the Hashashīn (Lewis, 1967. p. 30). They committed many political murders to create terror and fear in society (Frampton, 1929). Through espionage and assassins of political figures they killed two caliphs and a few sultans (Acosta, 2012). They posed a military threat to the Seljuk State through terrorist activities under the leadership of Sabbah. By capturing and inhabiting many unconnected mountain fortresses throughout Persia and Syria they threatened the Seljuk authority (Frampton, 1929).

However, when we examine the Hizmet Movement, we notice that the followers of the movement have no inclination towards any violence or radicalism (Hendrick, 2013). They are mostly mainstream Sunni Muslims as opposed to the rebellious Hashashīn. They practice the five daily prayers and other religious duties as moderate Muslims and never even attempt to resort to terror to promote their ideas. As a matter of fact, Turkey's AKP and its leader Erdogan have similar approaches with the Hashashīn because they have declared the Hizmet Movement as a heretic sect and then have usurped the properties of Gülen's sympathizers in Turkey. They have put thousands of people from this movement into prison, including many women with their newborn babies (The Fountain Magazine, 2017). Moreover, Erdogan and his AKP have deeply engaged in hate speech, discrimination and many more violent methods against the Hizmet Movement in an attempt to cover up their massive corruption and to secure their political power (Yeşilada, 2016).

The Diyanet has lost its objectivity in its opinions for it has become the political toy of the AKP. Opposing Turkey's religious affairs directorate, many Muslim scholars from all over the world have rejected the accusation of the Diyanet towards the Hizmet Movement. For instance, Prof. Abd al-Razzaq Gassum, the head of Scholars' Union in Algeria, professors Muhammad Nur Khalid and Ahmad Muqri from Nigeria, Prof. Fathi Hijazi from Egypt, Tahir Fal from Senegal, Prof. Osman Garib from Iraq and Cubak Calilov, the mufti of Kirgizstan, they all put their emphasis on one point: the Hizmet Movement is a moderate Islamic group which promotes peace, love, mercy, respect and universal human values; thus, it is a grave sin to accuse this movement with heresy. Again, Prof. Ali Juma, the former Mufti of Egypt, explained that the Hizmet Movement has been serving to God according to teachings of the Qur'an and Sunnah for a long time (Selim, 2016). He stated that Gülen's books have been translated into many world languages, including Arabic, in the last thirty years and during this period no one ever accused him with heresy or deviation. However, the Diyanet suddenly labelled the Hizmet Movement as a heretic sect obviously because of some political reasons. He argued that no one would believe the Diyanet for Gülen is a scholar who has promoted peace, mercy, respect and universal human values for over fifty years now. He concluded his 
statement with a call to the Diyanet: "Your declaration against the Hizmet Movement is not true, nor an Islamic act. Thus, do not be a political tool in the hands of corrupted politicians. All injustices of this world will appear as darkness in the Afterlife, so you better repent and amend your way before the Judgment Day" (Selim, 2016).

\section{The Relation between Absolute Obedience to the Ruler and Takfir}

Political Islamists argue that every Muslim must obey the ruler of Muslims (Karaman, 2017a). Hence, Erdogan is regarded as the caliph all Muslims must obey his authority (Karaman, 2017a). If any person or group disobeys him, they become disbelievers. According to their extreme mentality, it is not permissible to oppose Erdogan and his decisions. If anyone disobeys him or criticizes his political decisions, the severe punishment is applied by the state against him or her to protect the rule of the caliph (Kentel, 2016). They argue that if such opposition is not suppressed by the state, rebellious thought may spread out in society so quickly, turning into mass protests. They claim, therefore, any criticism against him must be punished severely in order to avoid rebellious activities against Erdogan's authority. With this extreme mentality, the AKP government has put thousands of innocent people in prisons, including 17.000 women (The Fountain Magazine, 2017). Worse than that, many women were put in prisons with their little kids (The Fountain Magazine, 2017). Obviously, this is an insane act and is not related in any way to Islam and its teachings.

Although Erdogan is a corrupt dictator, it is not permissible to criticize him in the mentality of these political Islamists (Karaman, 2013). For any criticism may undermine the legitimacy of the caliph and then the unity of Muslims (Karaman, 2014a). Obviously, interpreting religion with such a paradigm is beneficial only for the corrupt politicians, and not for the citizens. In Islam, however, the law is above all human beings, and people are equal before the law. Therefore, a ruler loses his legitimacy when he becomes a tyrant. Actually, when a politician exploits religion for his own political agenda in the name of holding power, he becomes more dangerous and extreme. This is mainly because religion has tremendous influence in society and by misleading the masses through the misinterpretation of religion, committing all kind of evils against the opponents become permissible. For this reason, I strongly believe that it is never permissible for politicians to make use of religious issues for their political agendas.

Pronouncing a person or a group "kafir" (unbeliever) is often used to describe an enemy to legitimize the physical force against him or her, including their murder and exile. Political Islamists such as Erdogan and the leading politicians in his AKP have been using "takfir" to consolidate their political power and eliminate all opponents (Yayla, 2017). They invite their followers to do "jihad" in a militant sense against the so-called apostates. They argue that jihad is incumbent on all Muslims to defend the caliph, Islamic lands and religious values. They publicly blame Christians and Jews for corrupting the world and straying from the true path (Karaman, 2017b). Moreover, they label all those Muslims who oppose their ideology as foreign spies, betrayers, enemies and apostates (Yilmaz \& Bashirov, 2018). Unfortunately, Erdogan provokes a war on religious grounds against his opponents and spreading his extreme mentality in all the directions of the world, east and west. 
Ironically, although Erdogan states that the supreme governance is for God, he sees himself untouchable and above everyone. This indicates that he likes people to worship him rather than worshipping God because in Islam, people are equal and no one is above the law. Although the masses in Turkey have been experiencing miserable conditions, severe poverty and corruption, the AKP government is able to suppress all criticisms against it by manipulating the power of religion.

As opposed to the political Islamists, people from the Hizmet Movement have not resorted to any armed struggle against Erdogan and the political Islamists although they are fully aware that there is no hope to gain their usurped rights through lawful means. This is mainly related to their understanding of Islam as it is not permissible to revolt against a ruler even if he is oppressor, tyrant and wrong doer. This is because an armed struggle against the state causes more injustices, wrong doings, corruption and greater turmoil in society (Sevindi, 2002). They have been suffering greatly as a result of losing their basic rights, and yet, they continue to protest Erdogan and his authoritarian regime through peaceful and lawful means.

Erdogan and the political Islamists believe that suppressing opponents by using religious concepts, including excommunication, is the simplest and surest method to consolidate their political power. Through the Directorate of Religious Affairs in Turkey, Erdogan's AKP regime has been controlling public opinions and suppressing all criticisms (Kenes, 2018). The imams (leading the prayers at mosques) who are appointed by the AKP regime have declared publicly that anyone who has not supported Erdogan and his caliphate would become an apostate, infidel and betrayer of their country (The Diyanet, 2016). Ignorant masses think that by disobeying Erdogan, the caliph of Muslims, the volunteers of the Hizmet Movement have abandoned Islam and that it was a religious duty to support Erdogan and his regime in his ruthless fight against the movement. Consequently, they assume that these devoted volunteers do not deserve any mercy and compassion. The unfortunate incidents in Turkey clearly show that political Islamists now lead a new form of extremism. Yet, this is more dangerous than the older extremists because they are more effective than those extremist groups with regards to convincing public to their extreme ideology.

Indeed, using religion for political purposes has made the Turkish society deeply divided. The entire society is now split into two major parts: pro-Erdogan and anti-Erdogan. With their extreme understanding, political Islamists have unleashed disunity, polarization and enmity in society. Erdogan and his followers have broken away from the moderate understanding of Islam and have represented an authoritarian regime instead of a democratic one. The sympathizers of the Hizmet Movement have disagreed with the extreme mentality of political Islamists and thus have stopped supporting the AKP despite the fact that they both have an Islamic background. In other words, the conflict between the reality and the political ideologies has caused these moderate Muslims to stand against the political Islam.

\subsection{Egocentrism in the Mentality of Erdogan and Its Relevance to Takfir}

The deviated groups that are under the tutelage of their extreme leaders are intolerant toward different ideas (Dogan, 2018a). They exclude debates while claiming that they are the only group who possesses the truth. They limit reasoning so that no one can question their evil 
practices. People in Turkey and the greater Muslim world are mostly ignorant of the true meaning of religion. They can, therefore, easily be manipulated by the extreme groups and political Islamists (Dogan, 2018b). They are unaw are of the real intent of Islamic teachings. For this reason, those who have evil goals can cherry-pick some verses and prophetic traditions out of their real context and then legitimize their injustices (Dogan, 2018a). They (mis)interpret only those religious texts which match with their evil purposes. They do not even bother to try to understand the Qur'an and the Sunnah in their totality and in line with the well-established Islamic principles.

Egocentrism is the inability to untangle subjective schemas from objective reality; it is an inability to understand or assume any perspective other than their own (Anderman, 2009). The issue of egocentrism is one of the most dangerous matters leading to blasphemy and tyranny. Following self-desires makes humans blind. They cannot see the truth except the one that matches their desires. The political ideology based upon egocentrism, such as political Islam in the interpretation of Erdogan, has lead people to commit unbelievably terrible crimes. If the Erdogan government has put thousands of innocent people in prison this is because they are driven by the extreme mentality of Erdogan. They have ruined the security and made people vulnerable to strife and unrest.

The concept of excommunication (takfir) on the basis of egocentrism has been accompanied by aggression towards the opponents. Initially, the notion of takfir was used only by terrorist groups, such as ISIS and al Qaeda, but now it has been used by political Islamists in more effective ways (Dogan, 2018b). Erdogan and his AKP regime have been using the takfir concept more effectively for they declare all opponents who do not follow their ideology as "unbelievers" (The Diyanet, 2016). The usage of takfir does not come from religion, but it comes from the misinterpretation of the religion by those who have violent ideas against other people. It is always related with the extremists. The takfir concept is often used by terrorist groups who consider themselves as "the guardians of religion."

When these extremists commit crimes, they call it "jihad" against the so-called apostates. Although Erdogan and his government have been proven to be corrupt, the misinterpretation of religion has given them opportunity to get away untouched with very major crimes (Kenes, 2018). Worse than this, they have punished innocent people to silence all the voices expressing their corruption. They have claimed that it is a religious duty to purge all those who criticize the government or talk about the corruption because they are sinful and Godless (Karaman, 2014a). In order to cleanse society from all opposing ideas they have justified violence and human rights violations against the opponents (Karaman, 2015).

Political Islamists have been supporting egocentric tendencies of Erdogan by claiming that all Muslims must submit their pledge to Erdogan, the caliph of Muslims, and obey him during both the times of prosperity and adversity (Samanyolu Haber, 2017, http://www.shaber3.com/gulen-firkasi-halife- ye-biat-etmedi-de vletin- yaptik larini- hak-ediyorhaberi/1288894/). This perspective made Erdogan spin around himself and consider himself as the core of the world and the center of attraction. With this religious justification, he has obliged everyone to obey him and follow his orders; otherwise, they become sinful, and thus, 
need to be eliminated. Due to his egocentric feelings, Erdogan believes that he has the right to speak while everyone else should listen. He assumes himself the leader and all others the followers. He deems his view as always right, but the opinions of the "others" wrong. The concept of self-sanctification in Erdogan's personality made him blind to the extent that he cannot see the truth. In short, there is a strong relation between the egocentrism of Erdogan and excommunicating those Muslims who are opposing him. Moreover, his egocentric feelings are the most serious cause of his extremism, tyranny and corruption.

Extremism and radicalism are destructive diseases and chronic illnesses. If a person is affected with these diseases, they isolate themselves. They are inclined to violence and terrorism. Openness is an effective way to reduce the extremism of individual selfishness. Through discussions and listening to other opinions, individuals can notice their extremism. They can learn higher values that open up debate, discussion, compromise and relationships. Self-criticism and control can also pave the way for healthy thinking. However, Erdogan and the AKP are never open to self-criticism, discussion or debate. They have thus become egocentric and authoritarian.

\subsection{Enjoying the Monopoly in Truth and Its Relation to Excommunication and Extremism}

Political Islamists have persuaded themselves that they are the only ones who know the absolute truth; they are, therefore, the only group who will enter Paradise and be saved from hell (Samanyolu Haber, 2017, http://www.shaber3.com/gulen-firkasi-halife-ye-biat-etmedi -devletin-yaptiklarini-hak-ediyor-haberi/1288894/). The idea of having absolute truth and seeing others as deviated have led Political Islamists to extremism. They no longer accept any debate, argument or any alternative opinion. Their extremism is at such a level that they even criticized the Noble Prophet while expressing their absolute correctness. Efkan Ala, the former minister of domestic affairs in the AKP government, once stated, "Prophet Muhammad fell into arrogance when he conquered Makkah but the AKP has never made such mistake" (YouTube, 2014, https://www.youtube.com/watch?v=e7qqvrtpCqY). Their arrogance is at such a high level that they even see themselves above the Prophet of Islam. This arrogance is the main reason for them to see themselves with the power to openly declare other Muslims as "apostates" and "unbelievers." They assume that they are right and everyone else is wrong. "Others" are deviated while they are true Muslims. Thus, there is no need to debate with the "others." Either all opponents stop opposing the political Islamists or they will be destroyed.

Political Islamists accept only people who obey them and follow their instructions without questioning. There is no middle way in the AKP mentality where people from different opinions meet and establish peace and harmony all together in society. The desire for silencing all opponents has been deeply embedded in their minds. Their despotic behavior is due to their belief of the elimination of "others" and deprivation of their lives, honor and other basic rights. On the basis of their extreme ideology, they threat and intimidate all other people who do not agree with them. They deprive opponents from their inalienable rights such as freedom, life and religion. The loss of peace, harmony, mutual respect and coexistence with others in Turkey are all results of this extreme mentality of the political 
Islamists.

The intolerance toward other opinions generates a sense of denying the people to the right of freedom of expression. Erdogan and the political Islamists in Turkey desire to dictate their own opinions upon all others. They like to control communal perc eption. In this regard, they have shut down all TV stations, newspapers and other media outlets who did not give their pledge of allegiance to the caliph (The Fountain Magazine, 2017). They even blocked online access to Wikipedia as well as Facebook and twitter accounts when they received serious criticism following the corruption allegations in 2013 (Kasapoglu, 2015). Moreover, the AKP government prevented access to You Tube and Twitter because they did not want public learn about their massive corruption (Kasapoglu, 2015).

\subsection{The Relation between Seeing Erdogan Holy and the Takfir}

Although Political Islamists have declared millions of Muslims who have sympathy toward the Hizmet Movement as kafir (unbelievers or apostates), they are not careful about abstaining from words and acts that contradict even with the basic tenets of Islamic faith. First of all, no one is divine or holy in Islam, but political Islamists see Erdogan as important as Prophet Muhammad. They organized birthday celebrations for Erdogan just like people celebrate the birthday of the Noble Prophet (Nettavir, 2018). They prepared flyers and billboard advertisements which contained red flowers (Nettavir, 2018). Muslims in some countries celebrate the birthday of Prophet Muhammad by distributing red flowers; thus, red flower is a symbol of his birthday. Using the same symbol to celebrate the birthday of Erdogan indicates the egocentric mentality of the political Islamists in Erdogan government. If not higher, they see Erdogan at the same level with the Prophet of Islam.

Many ministers, mayors and members of Erdogan's AKP have used expressions in which they considered Erdogan a holy man (Yilmaz \& Bashirov, 2018). They attributed him divine features. Even some AKP members called Erdogan as the second Prophet in Islam which is the exact opposite of Islamic faith. Some AKP members publicly claimed that it is "an act of worship to touch Erdogan." They even argued that a television in which Erdogan appeared should not be put on the ground level for it may imply a great disrespect to Erdogan's "holy" personality.

Egemen Bagis, the former minister of European Union in the AKP government, stated that some cities in Turkey such as Rize are blessed for Erdogan was born and raised there. He publicly expressed that the highest level of status for a person to achieve is being a friend of Erdogan (Nettavir, 2018). These words indicate that the former minister considers Erdogan holy; thus, he attached all religious honor and status to Erdogan's personality.

Hüseyin Şahin, the AKP Member of Parliament representing the city of Bursa, uttered the following words in a dinner to people who visited him: "Together with some friends we had a chance to chat with our president (referring to Erdogan). My friends asked some questions to our president and shook his hand. Indeed, for me it is an act of worship to touch Erdogan" (Nettavir, 2018). According to Islamic doctrines, worship is only performed to God alone. It is extremely prohibited to worship anything or anyone other than God. The greatest major sin 
in Islam is associating partners to God. By uttering these words, this AKP Member of Parliament opposed the essentials of Islamic belief, but no one among the political Islamists has even criticized him.

Mustafa Göktaş, another member of parliament representing the city Urfa in the AKP cabinet, did not hesitate to say that there was famine before the AKP government, but since when Erdogan has achieved the political power, there has ever been abundance and rain (Tas, 2014). He argued that God assigned Erdogan as the caliph of Muslims; thus, he will keep achieving political success and no one will be able to stop him. Obviously, seeing Erdogan as the reason of abundance and rain is problematic from religious perspective because natural events, including rain, are determined by God alone. No one is a partner to God with regards to controlling or directing natural events.

Fevai Arslan, another member of parliament representing the city of Düzce in the AKP cabinet, publicly expressed that Erdogan was similar to God because "he gathered all the attributes of God in his personality" (Tas, 2014). During a public election campaign, he gave a speech and declared Erdogan as the one who had all attributes of God. Seeing Erdogan as having the same attributes of God is shirk (associating partners to God). Ironically, although Political Islamists have been labeling other Muslims as "unbelievers/apostates" without having valid reasons and true evidences, they do not hesitate to deem Erdogan "holy" although it is strongly against the Islamic teachings. Indeed, there is a similarity between Erdogan's AKP and the terrorist groups who see themselves as the only true Muslims and declare others as "kafir" and then kill them brutally. Both have extreme approach to religion with regards to deeming all opponents as "apostates."

Ismail Hakk1 Eser, the member of AKP from the city of Aydın, expressed his love to Erdogan by saying, "We are so much loyal to our president Erdogan and fall in love with him, he is like the second Prophet for us" (Tas, 2014). The extreme mentality of political Islamists and their followers can further be seen from the following statements:

"I swear by God that Erdogan is Turkey's eternal president forever",

"To belong to AKP means to be officially wedded to the (then) Prime Minister",

"I recognize Erdogan as the caliph and submit my recognition",

"Our Prime Minister is the glad tidings of our Creator sent to humanity",

"Recep Tayyip Erdogan is the shadow of God on Earth",

"Erdogan is a leader who combines all attributes of God" (Tas, 2014).

Seeing Erdogan as eternal president pawed the way towards dictatorship. Rather than following democratic principles they obey Erdogan unconditionally and this blind obedience gives him extraordinary power. He determines the law and violates it when it contradicts him (Kenes, 2018). In this extreme ideology, Erdogan is above the law. He is the president forever; thus, if anyone challenges his authority he or she will be punished. Obviously, there is no place for opponents or alternative parties/leaders in the ideology of political Islamists. 
According to political Islamists, Erdogan is "the shadow of God on Earth" (Tas, 2014), and it is "a grave sin" to criticize him. Everyone must, therefore, submit themselves to Erdogan's authority, the shadow of God on Earth. If any group, no matter how sincere Muslims they are, oppose his authority and criticize his personality or politics, they deserve the severest punishment because the unity among Muslims can be established by absolute obedience to the so-called caliph (Samanyolu Haber, 2017, http://www.shaber3.com/gulen- firkasi-halife -ye-biat-etmedi-devletin-yaptik larini-hak-ediyor-haberi/1288894/). According to their mentality, "the leader of all Muslims" cannot be criticized or opposed. It is only the infidels or unbelievers who dare to oppose Erdogan, the leader of Muslims (Karaman, 2014b). Obviously, this ideology is not different from the extreme ideology of ISIS, al Qaeda or any other terrorist groups emerging in the Muslim majority societies. Political Islamists have distorted Islam by their extreme (mis)interpretation. The wrongness in their ideology has revealed itself in their very practice. Erdogan and his followers commit all kinds of persecution, torture and human rights violations against all those "dissidents" on the basis of their extreme ideology.

\section{Conclusion}

In Islamic history, takfir (excommunication) has been used by the extremists in an attempt to legitimize their violence against all those they deem as "the others." Erdogan and the political Islamists in Turkey have declared Gülen and his sympathizers as "apostates" and then performed all forms of injustices against them. They claimed that by disobeying Erdogan, the caliph of Muslims, the followers of Hizmet have abandoned the fold of Islam. Therefore, they deserve no mercy or compassion at all. Moreover, they have labeled Muslims who opposed their ideology as "foreign spies," "betrayers," and "enemies."

Political Islamists have been using "takfir" (excommunication) to consolidate their political power and to eliminate all opponents. Therefore, they have encouraged and highly motivated their zealot followers to do "jihad" (in a militant sense) against all those so-called apostates. They believe that it is a religious duty to exterminate all those who criticize Erdogan and his government in the society.

Excommunication of "others" in the ideology of the political Islamists is related to their misinterpretation of religion and using it merely for their political purposes. Their literal reading of both the Quranic verses and the hadiths, their lack of understanding of the profound true indications, meanings and aims of the primary Islamic sources as well as their erroneous interpretation of the religious texts are the basis for the extremism of Erdogan and his team of political Islamists in Turkey. Moreover, the so-called Islamic scholars who have supported the politicians for some worldly benefits make the problem worse because, with their evil religious rulings (fatwas), they deem all kinds of violence against the opponents as acceptable.

\section{References}

Abu Dāwud, S. (2008). Sunan Abi Dāwud. Beirut: Dar al-Kutub al-Ilmiyah.

Acosta, B. (2012). “Assassins” in "Cultural Sociology of the Middle East, Asia and Africa: 


\section{Macrothink}

An Encyclopedia”. In Carolyin, M. E. (Eds.). Los Angeles: Sage Publications.

Al-Isfahānī, R. (1997). Mu'jam Mufradat Alfaz al-Qur'an. Beirut: Dar al-Kutub al-Ilmiyya.

Al-Qushayri, M. (1996). Sahih Muslim. Delhi India: Adam Publishers.

Anderman, E. M. (2009). Egocentrism. Psychology of Classroom Learning: An Encyclopedia. 1, 355-357. Detroit: Macmillan Reference USA.

Baghdadi, A. (n.d.). Al-Farq Bayn Al-Firaq. Cairo: Muassasat Ibn Sina,

Baqillānī, M. (1957). Kitab al-Tamhid. Beirut: al-Maktabah al-Sharqiyah.

Bukhari, M. (1997). Sahih Bukhari. Riyadh: Darussalam Pub. \& Distr.

Çetin, M. (2010). The Gülen Movement: Civic Service Without Borders. New York, NY: Blue Dome Press.

Dāraqutn̄̄, A. (1966). Sunan al-Dāraqutnī. Medina: Dar al-Mahasin lịt-Tỉba' a,

Dogan, R. (2018a). Terrorism and Violence in Islamic History and Theological Responses to the Arguments of Terrorists. New York: Nova Science Publishers.

Dogan, R. (2018b). Political Islam (The Justice and Development Party in Turkey) Versus the Gülen Movement. Journal of Social Science Studies, 5(2), 89-105 http://doi.org/10.5296 /jsss.v5i2.13126

Esposito, J. L., \& Yilmaz, I. (2010). Islam and Peace-building: Gülen Movement Initiatives. New York, NY: Blue Dome Press.

Frampton, J. (1929). The Most Noble and Famous Travels of Marco Polo. London: The Argonaut Press.

Gölcük, Ş., \&Toprak, S. (2001). Kelam. Konya: Tekin Dagitim.

Hendrick, J. D. (2013). Gülen: The Ambiguous Politics of Market Islam in Turkey and the World. New York: New York University Press. https://doi.org/10.18574/nyu/978081477098 6.001 .0001

Ibn Ābidīn, M. (1987). Radd al-Mukhtar. Beirut: Dar al-Fikr.

Ibn Manzūr, M. M. (1999). Lisan al-Arab. Beirut: Dar Turath al-Arabi.

Jurjān̄̄, A. (2014). Kitab al-Tārifāt. Yemen: Al-Hakawati.

Karaman, H. (2013). Türkiye'nin dostlarl ve düssmanlarl. Available online: http://www.yeni safak.com/yazarlar/HayrettinKaraman/turkiyenin-dostlari-ve-dusmanlari-44456 Dec 19, 2013

Karaman, H. (2014a). Yolsuzluk başka hırsızlık başkadır. Available online: http://www.yeni safak.com/yazarlar/hayrettinkaraman/yolsuzluk-baka-hırsılık-bakadır-2006694Dec 21, 2014 Karaman, H. (2015). Birlik ve huzur düşmanlart. Available online: https://www.yeni safak.com/yazarlar/hayrettinkaraman/birlik-ve-huzur-dumanlari-2-2021818 
Karaman, H. (2017a). Neyi oyluyoruz? Available online: https://www.yenisafak.com/yazarlar /hayrettinkaraman/neyi-oyluyoruz-2037309

Karaman, H. (2017b). Europe does not want Islam and Muslims. Available online: https://www.yenisafak.com/en/columns/hayrettinkaraman/europe-does-not-want-islam-and- m uslims-2038967

Kasapoglu, C. (2015). Turkey social media ban raises censorship fears. Available online: https://www.bbc.com/news/world-europe-32204177

Kenes, B. (2018). Instrumentalization of Islam: Hayrettin Karaman's Role in Erdogan's Despotism. Available online: http://www.politurco.com/instrumentalization-of-islam-hayre ttin-karamans-role- in-erdogans-despotism.html

Kentel, F. (2016). The right to the city during the AK Party's thermidor. In Cizre U. (Ed), AK Party and its leader: criticism, opposition and dissent (pp. 132-165). London and New York: Routledge,

Lewis, B. (1967). The Assassins: A Radical Sect of Isla. Oxford: Oxford University Press.

Māturīī̄, M. (2006). Kitab al-Tawhid. Beirut: Dar al-Kutub al-Ilmiyya.

Nettavir. (2015). AKP'lileri dinden çıkartan şirk dolu sözleri. Available online: http://nettavir.com/akplileri-dinden-cikartan-sirk-dolu-sozleri/

Nowell, C. E. (1947). The Old Man of the Mountain. Speculum, 22(4). https://doi.org $/ 10.2307 / 2853134$

Rāzī, F. (1999). Mafātih al-Ghayb. Makka: al-Maktabaal- $\square$ A Asriya.

Samanyolu, H. (2017). Gülen firkası 'halife'ye biat etmedi devletin yaptıklarını hakediyor. Available online: http://www.shaber3.com/gulen-firkasi-halife-ye-biat-etmedi-devletin -yaptiklarini-hak-ediyor-haberi/1288894/ August 6, 2017

Selim, M. (2016). Hizmet hareketinin irtidat/tekfir ile ithams. Available online: http://www.shaber3.com/yazar/metin-selim/hizmet- hareketinin- irtidat-tekfir- ile- ithami/12775 $87 /$

Sevindi, N. (2002). Fethullah Gülen 'le Global Hosgoruve New York Sohbetleri (Interview with Fethullah Gulen on Global Peace), (pp. 28-29). Istanbul: Timas.

Shahristān̄̄, M. (1993). al-Milal Wa'n-Nihal. Beirut: Dar al-Ma'rifa.

Solaker, G. (2014). Turkish ruling party MP slams government in resignation, police purged. Available online: https://www.reuters.com/article/uk-turkey-corruption/turkish-ruling-party -mp-slams-government- in-resignation-police-purged-idUKBREA0U19420140131

The Diyanet (Turkish Directorate of Religious Affairs). (2016). Dini Istismar Hareketi FETÖ/PDY Raporu. Available online: http://gaihl.meb.k12.tr/tema/icerikler/din- isleri-yuksek -kurulu-baskanligi-tarafindan-hazirlanan-dini-istismar-hareketi-fetopdy-raporu_3464700.html 


\section{Macrothink}

Issues in Social Science

ISSN 2329-521X 2018, Vol. 6, No. 2

The Fountain Magazine. (2017). What Went Wrong with Turkey. The Foundation Special Issue. New Jersey: Blue Dome Press.

Taftazān̄i, S. (1991). Sharh al-Aqā'id. Istanbul: Dergah Yayınları.

Tas, H. (2014). Yeni Türkiye'nin Yeni Kültü. Available online: http://www.radikal.com.tr /radikal2/yeni_turkiyenin_yeni_kultu-1188716

Tirmidhī, M. (1967). Sunan Tirmidhī. Medina: al-Maktabah al-Salafiyah.

Yayla, (2017). Turkish referendum: when democracy falls short of a majority. Available online: https://www.huffingtonpost.com/entry/turkish-referendum-when-democracy-fallsshort-of-a_us_58f23649e4b048372700d8a9

Yazir, H. (2007). Hak Dini Kur'an Dili. Istanbul: Azim Dagitım.

Yeşilada, B. A. (2016). The future of Erdoğan and the AKP. Turkish Studies, 17, 19-30. https://doi.org/10.1080/14683849.2015.1136089

Yilmaz, I., \& Bashirov, G. (2018). The AKP after 15 Years: Emergence of Erdoganism in Turkey. Third World Quarterly. https://doi.org/10.1080/01436597.2018.1447371

YouTube. (2014). AKP Minister Efkan Ala: "The Prophet Prided Himself and Was Therefore Warned with a Divine Revelation, but We Have Not Taken Pride in Ourselves" ("Hz. Peygamber Gurura Kapıld1, Ayetle Uyarıldı, Biz Gurura Kapılmadık"). Available online: https://www. youtube.com/watch?v=e7qqvrtpCqY

Zabīdī, M. (1990). Tāj al-Arūs. Riyadh: Dar al-Fikr. 